Article

\title{
Impact of Export Promotion Programs on Export Performance
}

\author{
Jorge Mota ${ }^{1,2}$, António Moreira ${ }^{1, *(1)}$ and Alexandra Alves ${ }^{3}$ \\ 1 Department of Economics, Management, Industrial Engineering and Tourism, GOVCOPP—Research Unit on \\ Governance, Competitiveness and Public Policies, University of Aveiro, 3810-193 Aveiro, Portugal; \\ jorgemota@ua.pt \\ 2 CICEE-Research Center in Business and Economics, UAL, 1169-023 Lisboa, Portugal \\ 3 Department of Economics, Management, Industrial Engineering and Tourism, University of Aveiro, 3810-193 \\ Aveiro, Portugal; alexandraaalves@ua.pt \\ * Correspondence: amoreira@ua.pt
}

Citation: Mota, Jorge, António Moreira, and Alexandra Alves. 2021. Impact of Export Promotion Programs on Export Performance. Economies 9: 127. https://doi.org/ $10.3390 /$ economies 9030127

Academic Editors: Robert Czudaj and Andrea Appolloni

Received: 10 July 2021

Accepted: 28 August 2021

Published: 2 September 2021

Publisher's Note: MDPI stays neutral with regard to jurisdictional claims in published maps and institutional affiliations.

Copyright: (c) 2021 by the authors. Licensee MDPI, Basel, Switzerland. This article is an open access article distributed under the terms and conditions of the Creative Commons Attribution (CC BY) license (https:// creativecommons.org/licenses/by/ $4.0 /)$.

\begin{abstract}
This research examines the relationship of Export Promotion Programs (EPPs), sponsored by a Portuguese Regional Association for Development on Trade and Industry, with firms' export performance. To investigate this, two models were applied using panel data analyses that relate export performance to variables such as participation in EPPs, age and size of firms. Data on 198 firms for the sampling period 2010 and 2018 was drawn from a Portuguese Regional Development Association and SABI (Iberian Balance sheet Analysis System) database. The results show that participation in EPPs does have a positive influence on the export performance of firms, especially for those firms with previous export experience, demonstrating the importance of using these programs. Findings also document that firm size relates positively export performance, whereas firms age show a negative effect on export performance, suggesting that larger firms with more resources positively influence exports and an increase in firms' age may increase their cultural inertia, inability to change strategies, decreasing their export performance, respectively. Finally, the participation in EPPs seems not to influence export performance for firms without previous export experience. The research contributes to the literature providing evidence on the role of EPP on firms' export performance behavior promoted by regional development associations.
\end{abstract}

Keywords: internationalization; export promotion programs; export intensity

\section{Introduction}

Exporting is considered a crucial commercial activity for the economic well-being of firms and countries (Jalali 2012). With the globalization process, small and medium-sized firms (SMEs) face both new opportunities and new challenges as they lack for example resources and capabilities to explore foreign markets, knowledge of international markets, and international experience (Leonidou et al. 2007; Freixanet 2012; Ayob and Freixanet 2014). Thus, given the importance of exports for any country's economic development, it is crucial to understand the main drives of exporting activities (Geldres-Weiss and Monreal-Pérez 2018; Comi and Resmini 2020; Mata et al. 2021).

When firms are unable to carry out export activities due to their lack of experience, limited resources or other perceived or real obstacles, Export Promotion Programs (EPPs) may play an important role underpinning SMEs in their path to markets and networks abroad (Kang 2011). In addition, firms with different degrees of international involvement have different needs and face different obstacles (Francis and Collins-Dodd 2004).

Although several theories have been put down to explain the process of internationalization (Ribau et al. 2015; Paul and Sánchez-Morcilio 2019), one can claim that behavioral theories have become the most common ones in explaining the internationalization of SMEs. However, there is no single theory that can be exclusively used to explain the international path SMEs follow (Furtado et al. 2019; Paul and Sánchez-Morcilio 2019; Ribau 
et al. 2018a). Another factor affecting internationalization is fixed costs of exporting and the fact that SMEs typically cannot shoulder such fixed costs, which is explained by the standard Melitz (2003) model of international trade and heterogeneous firms. Despite the path, the internationalization process necessarily involves the commitment of human and financial resources, and this capacity increases according to the size of the firms.

SMEs' participation in export activities can be encouraged by internal and external change agents. The former emerges within the organization, such as resources and capabilities (Barney 1991). The latter are related to forces outside the organization, such as Export Promotion Programs (EPPs), organized, for example, by public entities (Ayob and Freixanet 2014; Comi and Resmini 2020; Malca et al. 2020) aiming at increasing the export intensity of SMEs.

There has been growing attention and concern in recent years for the impact of EPPs on firms, as these programs have increased in number and weight in government budgets (Freixanet 2012), but the results are far from being homogeneous (Coudounaris 2018; Comi and Resmini 2020; Crick 1992; Dominguez 2018; Haddoud et al. 2018; Malca et al. 2020; Quaye et al. 2017; Sharma et al. 2018).

It is essential to know whether and to what extent these EPPs are effective or not. In other words, it is necessary to assess the involvement of the firms in the processes of development of internationalization and to assess what are the main results achieved. Additionally, the effect of EPPs on firms export performance is still an under-researched topic, especially in Portugal, which is a European economy with some particular development standards vis-à-vis other European economies, with little literature on EPPs and internationalization. Furthermore, the mainstream research has analyzed EPPs promoted by national programs, and to the best of our knowledge there are a few studies analyzing programs proposed by regional development agencies that seek to promote the international intensity of their business associates. One important aspect of the EPPs programs is that they support SMEs the lack of information most of them have about foreign markets. For regional development associations it is a unique opportunity to support their associates, especially SMEs, exploring new markets that otherwise would not be able to with the limited resources they have.

Thus, studying this theme is relevant and pertinent since there is always a need for organizations that finance export promotion programs to improve and adapt their design and create better procedures for their implementation. On the other hand, the study is also important to provide business managers with pertinent information about the role and effect that these programs can play in their firms, increasing the credibility of these programs both in the eyes of public opinion and public entities that, regularly, finance them. As such, the main research question of this paper is the following one: Does the participation of firms in EPPs favor export performance? Thus, this paper has as main objective to assess whether the participation in EPPs positively affects export performance of Portuguese firms.

The study uses a sample of 198 Portuguese firms that participated in at least one export promotion program intermediated by a Portuguese Regional Association for Development on Trade and Industry, in the years 2011, 2013, 2014, and 2015 using a quantitative methodology based on the definition of two panel data econometric models. Primary data were drawn from this Portuguese Regional Association for Development on Trade and Industry, and secondary data were collected through the SABI Database (Iberian Balance Sheet Analysis System). Two empirical models, using different specifications for the variables under study, were estimated using panel data methodologies.

This paper is structured as follows: after this introduction, Section 2 presents the literature review. Section 3 presents the data used, the empirical specification, and the research method. Section 4 presents the empirical results. Section 5 presents Robustness Checks. Finally, Section 6 presents the conclusions and limitations of the study. 


\section{Literature Review}

The international environment is quite complex, since firms adopt many internationalization strategies aimed at serving global markets, taking on the associated challenges and risks, developing new products, or adapting their brands to international widely competitive environments. Moreover, the firms' internationalization process presupposes entering foreign markets, and embracing a growing international involvement and exposure. As such, firms can choose between various modes of entry in international markets, which implies the existence of different levels of commitment, control, and risk for the firm (Lu and Beamish 2001; Duygulu et al. 2016; Osland et al. 2001; Ribau et al. 2015).

Several theories have been put down to address the internationalization process of SMEs, in which internationalization can be considered as a gradual and evolutionary process with increased involvement in international markets or through relatively fast and intense process, according to the perspectives of the firm and the context (Cansino et al. 2013; Duygulu et al. 2016; Furtado et al. 2019; Johanson and Vahlne 2009; Oviatt and McDougall 1997; Paul and Gupta 2014; Ribau et al. 2015). Traditionally, export is the method most used by firms to enter international markets. This can be explained mainly by the fact that it is a method that requires minimal resources, involves low risks, at least when compared with other modes of entry, and allows greater structural and strategic flexibility for firms (Leonidou et al. 2011; Wilkinson et al. 2009).

There are several motivating factors that trigger firms' decisions to start and develop export activities. These stimuli can be classified as internal or external stimuli. On one side, internal stimulus are endogenous to the firm and can include for example, accumulation of unsold stock, interest in corporate growth, or possession of a unique product. Alternatively, external stimuli result from the environment in which the firm operates (for example, unsolicited orders from abroad, favorable exchange rates, incentives by government agencies) (Leonidou et al. 2007).

Additionally, the factors that stimulate exports can be classified as proactive or reactive. When firms react to contextual changes and understand internationalization as a response to those changes, they follow a reactive stimulus (e.g., seasonal effects of demand and saturation of the domestic market). If firms start their internationalization path seeking market opportunities or based on their own internal skills and competences, they follow a proactive stimulus (Ribau et al. 2018b; Westhead et al. 2004). Firms motivated by internal factors are usually described as more rational and objective in their export behavior, compared to those stimulated by external factors. Moreover, proactively stimulated firms are seen as more aggressive and strategic in relation to its export intensity, whereas when followed by reactive factors they adopt a much more passive and opportunistic approach to enter the foreign market (Ribau et al. 2018b; Westhead et al. 2004).

The resources and capabilities are important to explain how companies achieve competitive advantage and are able to serve national and international markets (Barney 1991). The importance of resources for firms is explained by the resource-based view (RBV) of the firm (Barney 1991). The RBV is an influential theoretical perspective that helps to understand the importance of resources and capabilities for firms to successfully explore international markets. Moreover, the lack of resources jeopardizes firms to effectively and efficiently achieve a competitive advantage and achieve superior customer value (Grant 1991; Peteraf and Barney 2003).

Many firms, especially SMEs, do not take full advantage of the potential of the foreign market due to their lack of motivation, capacity, and/or human and financial resources (Freixanet 2012). Compared to large firms, SMEs are more limited in terms of resources and capacities for acquiring information, which makes them less likely to start an unsupported export process (Leonidou et al. 2007).

When SMEs decide to start exporting to a specific country, their focus is on having representatives or establishing contacts with local distributors. This effort is challenging due to the asymmetry of information and geographical distance with foreign partners (Ayob and Freixanet 2014). 
The literature indicates that the complexity of the international business environment, the lack of motivation, information, and human and financial resources, puts SMEs at a disadvantage when competing internationally, not taking advantage of the potential of the foreign market. Compared to large firms, SMEs have less competent management and less skills to perform (Leonidou et al. 2007, 2011; Freixanet 2012; Wilkinson and Brouthers 2006): international marketing tasks; limited availability of financial, human and production resources; low market competitiveness due to lack of economies of scale; and a lower risk attitude when approaching the export business. These limitations end up conditioning the export intensity levels of SMEs (Wilkinson et al. 2009).

Exporting tends to be difficult as there are several barriers or inhibitors that hinder export performance (Wilkinson et al. 2009). Export barriers are treated in literature as attitudinal, structural, and operational restrictions that impede or hinder the firm's ability to initiate, expand, or maintain export operations. These restrictions can be found by the firm at any stage of the internationalization process (Morgan 1997). Export barriers, often (Leonidou et al. 2011) prevent potential exporters from engaging in export operations; interrupt exporters at an early stage to continue their activities abroad; undermine the performance of established exporters; and limit the expansion of "mature" exporters to more advanced forms of internationalization. Understanding how these barriers or inhibitors impede the export process is vitally important when trying to understand why and how firms engage in foreign markets, which can mitigate some of these export inhibitors (Wilkinson and Brouthers 2006).

Export promotion programs (EPPs) are programs implemented by public entities, trade associations, and other organizations to help firms, especially SMEs, overcome limitations on internationalization and reduce the negative effects of export barriers ( Francis and Collins-Dodd 2004; Leonidou et al. 2011). Taking into account that most SMEs have limited resources, those programs must be structured with clear objectives, low bureaucracy, and strong public-private partnership orientation so that SMEs can capture the full advantages of those programs (Ayob and Freixanet 2014).

In general, the objective of these programs is to act as an external resource to improve the firms export performance. It can be achieved by improving the capacities, resources, knowledge, experience, strategies of the firms, and the general competitiveness, which in turn, positively influences export performance (Francis and Collins-Dodd 2004; Gençtürk and Kotabe 2001; Leonidou et al. 2011).

The main roles of EPPs are to motivate firms, especially SMEs, to internationalize, reduce, or eliminate existing export barriers, assist in planning and preparing for export and providing financial and non-financial support (Ayob and Freixanet 2014).

These programs also aim to create a more positive attitude in the minds of managers in relation to opportunities for profit and growth abroad, minimizing negative perceptions about risks, costs, and complexities associated with exports. Information is a highly important organizational resource, as it helps the firm to reduce the high level of uncertainty that characterizes the international business environment. Therefore, many export promotion programs provide useful assistance with information, usually focusing on foreign country profiles, international business practices, and contacts with potential foreign partners (Leonidou et al. 2011).

There are several types of EPPs, which vary according to the particularities and needs of each country. In several developing countries, the focus is on promoting technological advancement and improving access to credit, while in developed countries, the most pertinent programs include establishing foreign trade offices, creating business, contacts, and providing a continuous flow of information for firms (Coudounaris 2012, 2018; Dominguez 2018; Malca et al. 2020; Comi and Resmini 2020).

For this reason, when designing EPPs, it is important to ensure that they provide specific assistance according to different needs and depending on the firm's export stages (Ayob and Freixanet 2014; Haddoud et al. 2018; Dominguez 2018). Furthermore, the need for export assistance also depends on the international experience of firms, as they face 
different obstacles (Crick 1992; Francis and Collins-Dodd 2004; Malca et al. 2020). Globally, EPPs can range from training seminars, assistance with export procedures, and advice on exports, trade fairs and missions, agent and distributor identification programs, among others. Finally, although EPPs are available to all firms, regardless of their size, due to their limited resources and capabilities, SMEs are considered to need these programs the most (Wilkinson et al. 2009; Leonidou et al. 2011; Quaye et al. 2017; Sharma et al. 2018).

There is a wide variety of types of export assistance provided by public entities and other organizations. An important area is the provision of information, for example, about the export market, market research in foreign markets, and export marketing seminars (Coudounaris 2012, 2018; Sharma et al. 2018; Comi and Resmini 2020).

Other programs are used in order to increase the firms' motivation to export, through seminars, speeches, case studies, and other communication materials. Operational support, in turn, includes training in export logistics, marketing assistance, trade missions, financial support, visits by foreign buyers, provision of contacts, and regulatory assistance (Francis and Collins-Dodd 2004).

Similarly, Gençtürk and Kotabe (2001) consider that export promotion assistance generally comprises export service programs, such as seminars for potential exporters, export advice, export instruction manuals, export financing, and market development programs, such as sales dissemination, firm visits, participation in trade fairs, preparation of market analyses and export newsletters. The availability of export financing is also crucial. This financial assistance can be made through capital loans, direct and indirect subsidies, such as exchange rate, tax incentives, and exemption from value added taxes due to the consequences on the capital structure during the internationalization process (Ayob and Freixanet 2014; Mota and Moreira 2017).

Export assistance for SMEs has increased over time, as has the need to assess the effectiveness and influence of EPPs. However, there is no consensus on how this analysis should be carried out and the literature in this area has addressed the theme in different ways addressing programs, as well as firms (Francis and Collins-Dodd 2004; Ayob and Freixanet 2014; Quaye et al. 2017; Haddoud et al. 2018; Sharma et al. 2018; Comi and Resmini 2020).

The literature focused on the economic evaluation of internationalization programs is generally based on surveys that request the evaluation by the recipients or on studies focused on a quantitative approach, in particular, cost-benefit analyses. Experts in this area value the amount of information obtained from surveys, but they doubt its reliability, noting that these assessments may be unsatisfactory for several reasons, such as the reluctance of firms to criticize the promotion program that, in many cases, did not have costs or had relatively modest costs (Cansino et al. 2013; Quaye et al. 2017; Haddoud et al. 2018; Sharma et al. 2018; Malca et al. 2020).

There are several indicators of export performance of firms that are divided between:

- Economic measures based on: sales (proportion of export sales and growth in export sales), profits (export profitability and growth in export profitability), and market share (e.g., Comi and Resmini 2020);

- Non-economic measures related to products, export markets (such as country of export and penetration in export markets) and other factors, such as number of years of exporting activities (e.g., Sharma et al. 2018; Malca et al. 2020);

- Generic measures, including perceived success in exports, achievement of export objectives, satisfaction with specific and general indicators of export performance (e.g., Quaye et al. 2017; Haddoud et al. 2018; Dominguez 2018).

Although there are a large number of export performance measures, only a few are used frequently, such as export sales intensity, export sales growth, export profitability, export sales volume, and growth in export sales intensity (Katsikeas et al. 2000).

One of the difficulties in measuring the effect of EPPs stems from the fact that export promotion is not a business activity itself. Instead, it facilitates business activities in a variety of ways. Moreover, many factors, of which EPPs are just one, influence the behavior 
and performance of firms' exports. As such, it becomes difficult to separate the effect of export promotion from the effect of other factors (Francis and Collins-Dodd 2004).

The diversity of factors that affect the success or failure of EPPs makes it unlikely that the results of a program can be directly linked to a single variable. With this, these factors must be considered and controlled in some way (Cansino et al. 2013). Moreover, the size of the firms significantly moderates the effect of EPPs, in particular, the programs related to information and training (Leonidou et al. 2011).

Tiago et al. (2008) conclude that the age of the firm reveals its stability, maturity, and the accumulation of knowledge necessary to carry out initial export activities and may explain the expansion of the export activities of the firms. Malca et al. (2020) also defend that previous experience in international markets, as well as previous year export performance affect the export performance of the current year. As such, there is a need for some maturation and organizational development for a firm to engage in export activities and, consequently, the propensity and intensity of exports is expected to be greater in older firms as they are expected to have more international (export) experience.

Cansino et al. (2013) demonstrate that firms that participate in EPPs have a higher proportion of exports than those that do not. They conclude that these programs are favorable to firms that decide to export by improving their knowledge of the entire export procedure, helping firms to eliminate or mitigate the initial difficulties associated with exports. However, if the participation in EPPs is important, Sharma et al. (2018) claim that EPPs support industrial SMEs with information and knowledge mitigating negative perceptions of foreign markets. Moreover, they claim that the attractiveness of foreign markets should not be overlooked, as it is an important mediator enhancing export performance.

Similarly, Alvarez (2004) concludes that certain types of export promotion programs, such as exporter committees, have a positive and significant impact on export performance. Comi and Resmini (2020), assessing EPPs among micro and small-sized firms in Lombardy, also conclude that EPPs increase both the export propensity and the export intensity of the firms that use them when compared to the results obtained by non-assisted firms. If participating in EPPs is important, high commitment entry modes are also important as Dominguez (2018) claims that risk-seeking firms seek operational and financial support whereas risk averse firms seek informational and motivational support, which not only differentiates those two different behaviors, but also their results. This supports Crick's (1992) assertions that claim that exporting firms should not be understood as an homogenous pack as their needs depend, on one side, on their level of resources, internationalization, information of international markets and, on the other hand, on their level of success.

The participation in EPPs sometimes displays contradictory results. For example, Malca et al. (2020) show that EPPs' information-, education-, and training-related programs do not affect export-related organizational resources. As such, in order to support Peruvian decision-makers to overcome their export-related mental barriers, EPPs needed to improve proactive approach to internationalization. Based on national EPPs programs in Ghana, Quaye et al. (2017) conclude that trade shows and trade missions achieve different results. In the same token, Haddoud et al. (2018), based on a survey questionnaire regarding the support of the Algerian Chamber of Commerce, report that trade shows and trade fairs may have positive and negative outcomes. As such, not all EPPs are successful in achieving better export promotion results, which might be explained by the resource endowments, information and knowledge of international markets, and proactive commitment of the SMEs involved in those programs. Clearly, the results obtained by at national level are not uniform.

Thus, although there are some contradictory results in the literature, previous research indicates that EPPs can be fruitful for firms under a variety of conditions. However, how productive they will be depends on the activities carried out and the ability and/or willingness of firms to take advantage of these programs (Wilkinson and Brouthers 2006; Dominguez 2018). 


\section{Data and Empirical Implementation}

In this research, a panel data approach was used, within a post-positivist paradigm. To this end, two empirical models were specified in an attempt to relate different specifications of the variables under study (e.g., Neuman 2012; Sobh and Perry 2006).

\subsection{Data Description}

This study analyzes the behavior of Portuguese firms participating in export promotion programs. For that, primary data were used that were made available by a regional development association that organizes these programs on firms participating in those EPPs. The sample includes a total of 198 Portuguese firms, which willingly participated in at least one of the four EPPs brokered by this regional development institution. The four programs analyzed took place during the years 2011, 2013, 2014, and 2015. In order to assess the economic outputs, the sample period covered the years from 2010 to 2018. In the years 2012, 2016, and 2017 the regional development association did not organize any EPP. As such, with this time frame, it was possible to cover a period of time encompassing the firm's economic performance, before and after participating in any EPP organized by the regional development association.

Most corporate finance decisions are taken by self-selecting from the preferred choices of decision-makers. Two main approaches to address self-selection problems can be used (e.g., Li and Prabhala 2007): (i) the Heckman baseline model for self-selection, and models generalizing the Heckman selection procedure (e.g., switching regressions and structural self-selection models); and (ii) matching models.

Matching models hold the assumption that unobserved private information is irrelevant to outcomes, contrasting with self-selection models, e.g., Heckman baseline model. If a corporate finance decision is made through an exogenous process, the impact of the unobserved private information on the outcome may be irrelevant and the dimension-bydimension matching models may be more accurate for the estimates. However, matching on several firm characteristics poses severe difficulties, such as: the exact matching of firm characteristics; and dimensionality of the matches when raising the dimensions to be matched.

Therefore, in our analysis, we did not use a control sample build using a matching procedure, but robustness checks of the main sample (by industry, by export experience, by intensity of participation in EPP) to mitigate the problems associated with building a control sample. Additionally, on SABI there is no information released on the participation in EPP, nor when that participation happens. As such, we gathered the data on firms' participation on EPP from a regional development association that organizes these programs.

The firms vary in terms of size, age, and sector of activity. The only criterion for choosing the firms was the participation in one or more of the EPPs of this regional development association. This information was released by the regional development association. As such, it is not a sample of firms that was randomly selected as we only worked with the firms that willingly participated in the EPPs provided by the regional development association.

Subsequently, secondary data were obtained through the SABI Database, where relevant information for the study was collected, regarding information from participating firms between the years 2010 and 2018 - the volume of domestic, community, extracommunity, and total sales (in thousands of euros) and the dimension, represented by the total number of employees. Additionally, age was also collected over the years 2010 and 2018 and the NACE (Nomenclature of Economic Activities) code of each firm.

The analyses are carried out between the years 2010 and 2018 because the participation in EPPs tends not to have short-term effects. Usually firms need a longer period of time to capitalize on the knowledge acquired and the contacts made when participating in these programs (Geldres-Weiss and Monreal-Pérez 2018). The econometric models were estimated using Stata. 


\subsection{Model Specification}

The empirical models specified in the present study are adapted mainly from the model used by Geldres-Weiss and Monreal-Pérez (2018).

In this paper, two alternative models were specified to assess export performance according to the following variables: age, size, and participation in export promotion programs. Alternative specifications were used in order to strengthen the results obtained.

Model 1:

$$
T E S_{i t}=\beta_{0}+\beta_{1} \text { Part_EPP }_{i t}+\beta_{2} \text { Size }_{i t}+\beta_{3} \text { Age }_{i t}+\beta_{4} \text { Yeardummy } y i+\varepsilon_{i t}
$$

\section{Model 2:}

$$
T E S / T E_{i t}=\beta_{0}+\beta_{1} \text { Part_EPP }_{i t}+\beta_{2} \text { Logsize }_{i t}+\beta_{3} \text { Logage }_{i t}+\beta_{4} \text { Yeardummy }_{y i}+\varepsilon_{i t}
$$

All variables pertain for firm $i$ and year $t$.

\subsection{Description of Variables}

\subsubsection{Dependent Variables}

In model 1, the dependent variable was total external sales (TES), in thousands of euros, specified as the export activity of the firms, following Geldres-Weiss et al. (2016). In model 2, the dependent variable was the ratio between total external sales and total sales (TES /TS) of the firm, as a percentage, representing the export intensity of the firms. In this case, since the dependent variable is in percentage, the remaining variables used in this model were logarithmized. Dependent variables can be seen in Table 1. The specification of this variable was based on the work of Fernández and Nieto (2005).

Table 1. Overview of variables and econometric models.

\begin{tabular}{lcc}
\hline Dependent Variables & Variable Definition & Data Source \\
\hline TES (Model 1) & $\begin{array}{c}\text { Total External Sales (thousands of } \\
\text { euros) }\end{array}$ & SABI \\
\hline TES/TE (Model 2) & $\begin{array}{c}\text { Ratio between Total External Sales } \\
\text { and Total Sales }\end{array}$ & SABI \\
\hline Independent Variables & Number of employees & SABI \\
\hline Size & Number of years since foundation & SABI \\
\hline Age & $\begin{array}{c}\text { Participation in an EPP in a given } \\
\text { year-dichotomous variable }\end{array}$ & $\begin{array}{c}\text { Regional Development } \\
\text { Association }\end{array}$ \\
\hline Part_EPP &
\end{tabular}

\subsubsection{Independent Variables}

Since there are a large number of conditions and elements that can affect firms export behavior, it is essential to include control variables in the specified models (Francis and Collins-Dodd 2004; Leonidou et al. 2011). The independent variables, which are shown in Table 1, used in the two models were:

- The age of the firm $(A g e)$ is one of the most used variables in the export literature and is determined by the number of years that have passed since the firm was founded (Comi and Resmini 2020; Geldres-Weiss and Monreal-Pérez 2018; Monreal-Pérez et al. 2012);

- The size of the firm (Size) is measured by the number of employees of the firm (Comi and Resmini 2020; Fernández and Nieto 2005; Geldres-Weiss and Monreal-Pérez 2018; Monreal-Pérez et al. 2012). It is an important variable because, compared to large firms, smaller firms suffer from limitations in terms of resources and capacities and 
are less likely to start export processes without support (Freixanet 2012; Leonidou et al. 2011; Wilkinson and Brouthers 2006);

- The models also include the EPP participation variable (Part_EPP). This is a dichotomous variable that indicates whether or not the firm participated in an EPP in a given year (Geldres-Weiss and Monreal-Pérez 2018). There were four programs included in the study, which took place in the years 2011, 2013, 2014, and 2015;

- Finally, a year dummy variable was created in order to control the years in which the considered observations occur.

\section{Econometric Analysis and Discussion of Results}

Table 2 documents the participation of the firms studied in the four EPPs of 2011, 2013, 2014, and 2015. It can be seen that the number of firms that participated in EPPs increased significantly during the third program (P2014), having been the program with the highest numbers of participating firms. Of the 198 firms analyzed, 162 participated in one EPP, 24 participated in two, 8 participated in three, and 4 participated in four EPPs.

Table 2. Sample description: participation in EPPs.

\begin{tabular}{cc}
\hline Program & Firms \\
\hline P2011 & 42 \\
P2013 & 42 \\
P2014 & 99 \\
P2015 & 69 \\
\hline Total number of firms & 198 \\
\hline
\end{tabular}

As can be seen in Table 3, firms represent broad sectors of the economy. Firms from the manufacturing industry are highly represented, with $67 \%$ of the sample. Next, follows firms from the wholesale and retail trade sector.

Table 3. Sample description: main industries.

\begin{tabular}{lc}
\hline \multicolumn{1}{c}{ Industry } & Firms (\%) \\
\hline Manufacturing industries & $133(67 \%)$ \\
Wholesale and retail trade; motor vehicle and motorcycle repair & $25(13 \%)$ \\
Consulting, scientific, technical, and similar activities & $12(6 \%)$ \\
Information and communication activities & $9(5 \%)$ \\
Construction & $6(3 \%)$ \\
Transport and Storage & $3(1 \%)$ \\
Others & TOTAL \\
\hline
\end{tabular}

The industry structure in this empirical research is in line with the studies carried out by Cansino et al. (2013), Sharma et al. (2018), Malca et al. (2020), Quaye et al. (2017), Haddoud et al. (2018), and Dominguez (2018) where the firms with the highest participation in the analyzed EPPs were from the extractive, industrial, and manufacturing industries.

Table 4 reports the descriptive statistics of the variables under analysis in the two specified models. We can see that the average age of the firms analyzed is 27 years and the oldest firm is 110 years old. Additionally, firms exhibit an average size of 46 employees, and the largest firm has 403 employees. Moreover, the average of the firms' total external sales is approximately 2232 thousand euros. The firms documenting total external sales equal to zero were the ones without export experience. Firms reporting size and age equal to zero were the ones that did not exist at the beginning of the sample period, or that ceased to exist at the end of the sample period, thus contributing to mitigate survivorship bias problems. 
Table 4. Univariate statistics.

\begin{tabular}{|c|c|c|c|c|c|}
\hline Variables & Obs & Mean & $\begin{array}{l}\text { Standard } \\
\text { Deviation }\end{array}$ & Min & Max \\
\hline TES & 1669 & 2231.638 & 4821.245 & 1 & 49,816 \\
\hline TES/TS & 1468 & 0.3580 & 0.3308 & 0.0002 & 0.9998 \\
\hline Size & 1653 & 45.7622 & 57.4225 & 1 & 403 \\
\hline Log(Size) & 1653 & 3.1715 & 1.2593 & 0 & 5.9989 \\
\hline Age & 17,511 & 27.1644 & 20.9793 & 1 & 110 \\
\hline Log(Age) & 1751 & 3.0127 & 0.8630 & 0 & 4.7005 \\
\hline Part_EPP & 1782 & 0.5039 & 0.5001 & 0 & 1 \\
\hline Part_EPP L1 * & 1584 & 0.4419 & 0.4968 & 0 & 1 \\
\hline
\end{tabular}

* lagged variable for one period.

Table 5 reports the correlations between the original variables used in model 1 . The correlation between size and total external sales $(0.7534)$ is the one that exhibits the highest value. The correlation between the remaining pairs of variables documents positive and statistically significant relationships.

Table 5. Pairwise correlation values (untransformed original variables).

\begin{tabular}{lcccc}
\hline & $\mathbf{1}$ & $\mathbf{2}$ & $\mathbf{3}$ & $\mathbf{4}$ \\
\hline 1. Total External Sales & $1.0000^{* * *}$ & 1.0000 & & \\
2. Size & $0.7534^{* * *}$ & $0.3423^{* * *}$ & 1.0000 & \\
3. Age & $0.1831^{* * *}$ & $0.0811^{* * *}$ & $0.1750^{* * *}$ & 1.0000 \\
4. Part_EPP & $0.0742^{* * *}$ & &
\end{tabular}

Results reported in Table 6 for models 1 and 2 were estimated using generalized least squares (GLS) regression of random effects (RE). The Hausman test was conducted to ascertain which estimators, the fixed or random effects, were more efficient (Hausman 1978). Under the Hausman test specification, the hypothesis that the individual-level effects are adequately modeled by a random-effects model is not rejected (Hausman test statistic 9.38 and $p$-value $0.4969-$ model 1; Hausman test statistic 9.20 and $p$-value $0.6033-$ model 2 ). Therefore, henceforward we only report the random effects estimates. The regressions were carried out to test the effect of the use of the EPPs on firms' exports.

Table 6. RE GLS regression (models 1 and 2) of the effect of EPPs on firm exports.

\begin{tabular}{llll}
\hline Model 1 & \multicolumn{3}{l}{ Model 2 } \\
\hline Size & 71.1697 & $\log ($ Size) & 0.0458 \\
& $(32.51)^{* * *}$ & & $(4.24)^{* * *}$ \\
Age & -23.8999 & $\log ($ Age) & -0.0107 \\
& $(-2.34)^{* *}$ & & $(-0.45)$ \\
Part_EPP & 357.0644 & Part_EPP & 0.0264 \\
& $(2.67)^{* * *}$ & & $(2.13)^{* *}$ \\
Year Dummy & Yes & Year Dummy & Yes \\
Obs & 1669 & Obs & 1457 \\
$\mathbf{R}^{2}$ & 0.5742 & $\mathbf{R}^{2}$ & 0.0733 \\
Const & -548.56 & Const & 0.1985 \\
& $(-1.34)$ & & $(2.71)^{* * *}$ \\
\hline
\end{tabular}

Note: values enclosed between parentheses are Z statistics; ${ }^{* * *} p<0.01 ;{ }^{* *} p<0.05$.

Approximately $57.42 \%$ of the variation in total external sales can be explained by the variables of size, age, and participation in EPPs (model 1) whereas only 7.33\% of the variation in the difference between total external sales and total sales can be explained by model 2. 
In Table 6 , model 1 , it is possible to verify that the variables size and age are statistically significant at $1 \%$ and $5 \%$, respectively. As such, size positively affects $(\beta=71.17)$ the dependent variable. This result shows that the larger the firm the larger their exports, which can be explained by the fact that larger firms have more resources and capacities to face internationalization (Freixanet 2012). However, age influences negatively $(\beta=-23.9)$ the export performance, which means that younger firms tend to use EPPs rather than older firms. This can be justified by cultural inertia, inflexibility, and inability to change strategies and/or behaviors that increase with the age, i.e., older firms may be slower to respond to changes than younger firms. Thus, since export activities require extensive changes in firms' operational activities, the older ones may have more difficulty in responding to this need than the younger ones (Kirpalani and Macintosh 1980; Love et al. 2016). Another possible explanation is that as this was a voluntary participation, some older firms with less international experience that need assistance from EPPs also participated.

The variables size and participation in EPPs are statistically significant at $1 \%$ and 5\%, in model 2. These results demonstrate that both variables positively affect the dependent variable. On the other hand, age is not statistically significant and does not influence export performance.

The variable participation in EPPS is statistically significant in the two models. The results demonstrate that the participation on EPPs is associated with firms' exports in the two specified models, given an affirmative answer to the research question initially raised.

Given that the manufacturing industry is the most prominent sector in the sample analyzed in this paper (see Table 3), we tested the existence of differences between this industry and the whole sample. Thus, the estimates of the two defined models were carried out again, but this time, considering the manufacturing industries. The results of the estimates are shown in Table 7.

Table 7. RE GLS regression (models 1 and 2) considering manufacturing industry.

\begin{tabular}{llll}
\hline Model 1 & \multicolumn{3}{c}{ Model 2 } \\
\hline Size & 73.3355 & $\log ($ Size) & 0.0385 \\
& $(29.04)^{* * *}$ & & $(3.03)^{* * *}$ \\
Age & -24.0167 & $\log ($ Age) & -0.0175 \\
& $(-1.85)^{*}$ & & $(-0.63)$ \\
Part_EPP & 456.4475 & Part_EPP & 0.0259 \\
& $(2.59)^{* *}$ & & $(1.88)^{*}$ \\
Year Dummy & Yes & Year Dummy & Yes \\
Obs & 1139 & Obs & 1102 \\
$\mathbf{R}^{2}$ & 0.5919 & $\mathbf{R}^{2}$ & 0.0530 \\
Const & -795.6299 & Const & 0.2875 \\
& $(-1.34)$ & & $(3.19)^{* * *}$ \\
\hline
\end{tabular}

Note: values enclosed between parentheses are Z statistics; ${ }^{* *} p<0.01 ;{ }^{* *} p<0.05 ;{ }^{*} p<0.1$.

In relation to the regressions carried out taking into account the manufacturing industries, all signs remained the same (both positive and negative) and, in general, the statistical significance did not change. Table 7 , model 1, shows that all variables are statistically significant, with size and participation in EPP positively affecting the dependent variable, while age affecting negatively, with similar coefficient values as those obtained with the whole sample, shown in Table 7.

The results for model 2 again demonstrate that the variables size and participation in EPPs are positive and statistically significant, but age is not statistically significant. Similar results were obtained from model 2 in Table 7.

All of the main results are in line with those obtained previously when performing the regressions for the whole sample. As such, it is possible to conclude that, to a large extent, the signs of the coefficients and the statistical significance do not change between the initial regressions and the new regressions carried out for the manufacturing industries. 
In short, regarding the variables size and age, it is concluded that size positively affects export performance, which corroborates studies of Freixanet (2012), Leonidou et al. (2011) and Wilkinson and Brouthers (2006), and in contrast, age has been shown to negatively affect export performance, which is in line with the work of Love et al. (2016).

The global results of the regressions carried out for the two models suggest that participation in EPPs positively influences the export performance of firms, as shown in Table 8.

Table 8. Summary of Results

\begin{tabular}{lccc}
\hline Dependent Variable & $\begin{array}{c}\text { Independent } \\
\text { Variable }\end{array}$ & Expected Signal & Research Question \\
\hline TES (Model 1) & Participation in EPPs & + & $\begin{array}{c}\text { Does the participation } \\
\text { of firms in EPPs favor } \\
\text { export performance? }\end{array}$ \\
\hline
\end{tabular}

This result, based on EPPs carried out by a Portuguese Regional Association for Development on Trade and Industry is in line with mainstream literature that states that firms that participate in EPPs tend to have a greater propensity, intensity, and proportion of exports, being, therefore, programs favorable to firms that willingly seek to increase their international reach.

These programs are considered tools that allow the acquisition of knowledge and improvement of resources, capacities, experience, and strategies, which help to minimize the risk and uncertainty of export operations leading to successful exports (Alvarez 2004; Cansino et al. 2013; Comi and Resmini 2020; Geldres-Weiss and Monreal-Pérez 2018).

\section{Robustness Checks}

To check for robustness of the regression results, we tested the existence of differences between firms that participated in only one EPP (single users) and firms that participated in two or more EPPs (heavy users), and between firms with former export experience (that already reported total external sales higher than zero in the year 2010) and without former experience (that reported zero total external sales in the previous year of their first EPP). Thus, the estimates of the two defined models were carried out, considering single users and heavy users-reported in Table 9-and firms with or without previous export experience-reported in Table 10.

Table 9. RE GLS regression (models 1 and 2) of the effect of EPPs on firms' exports for single EPP user vs. heavy EPPs users.

\begin{tabular}{|c|c|c|c|c|c|}
\hline \multirow[t]{2}{*}{ Model 1} & \multicolumn{5}{|c|}{ Model 2} \\
\hline & Single-user & Heavy-user & & Single-user & Heavy-user \\
\hline Size & $\begin{array}{l}81.5138 \\
(36.19) * * *\end{array}$ & $\begin{array}{l}46.7178 \\
(8.88)^{* * * *}\end{array}$ & $\log ($ Size $)$ & $\begin{array}{l}0.0449 \\
(3.93)^{* * *}\end{array}$ & $\begin{array}{l}0.0293 \\
(0.89)\end{array}$ \\
\hline Age & $\begin{array}{l}-32.7939 \\
(-3.13)^{* * *}\end{array}$ & $\begin{array}{l}-10.8471 \\
(-0.36)\end{array}$ & Log(Age) & $\begin{array}{l}-0.0001 \\
(-0.00)\end{array}$ & $\begin{array}{l}-0.1039 \\
(-1.49)\end{array}$ \\
\hline Part_EPP & $\begin{array}{l}207.3742 \\
(1.56)\end{array}$ & $\begin{array}{l}1144.61 \\
(2.51)^{* *}\end{array}$ & Part_EPP & $\begin{array}{l}0.0131 \\
(0.90)\end{array}$ & $\begin{array}{l}0.0907 \\
(3.14) * * *\end{array}$ \\
\hline $\begin{array}{l}\text { Year } \\
\text { Dummy }\end{array}$ & Yes & Yes & $\begin{array}{l}\text { Year } \\
\text { Dummy }\end{array}$ & Yes & Yes \\
\hline Obs & 1349 & 320 & Obs & 1148 & 309 \\
\hline $\mathbf{R}^{2}$ & 0.6359 & 0.4764 & $\mathbf{R}^{2}$ & 0.0777 & 0.0165 \\
\hline Const & $\begin{array}{l}-625.6996 \\
(-1.55)\end{array}$ & $\begin{array}{l}-65.371 \\
(-0.05)\end{array}$ & Const & $\begin{array}{l}0.1689 \\
(2.18) * *\end{array}$ & $\begin{array}{l}0.5736 \\
(2.32) * *\end{array}$ \\
\hline
\end{tabular}

Note: values enclosed between parentheses are Z statistics; ${ }^{* * *} p<0.01 ;{ }^{* *} p<0.05$. 
Table 10. RE GLS regression (models 1 and 2) of the effect of EPPs on firms' exports for firms with former export experience vs. firms without former export experience.

\begin{tabular}{|c|c|c|c|c|c|}
\hline \multirow[t]{2}{*}{ Model 1} & \multicolumn{5}{|c|}{ Model 2} \\
\hline & $\begin{array}{l}\text { Export- } \\
\text { Experience } \\
(\mathrm{EE})\end{array}$ & Without EE & & $\begin{array}{l}\text { Export- } \\
\text { Experience } \\
\text { (EE) }\end{array}$ & Without EE \\
\hline Size & $\begin{array}{l}73.0458 \\
(29.09)^{* * *}\end{array}$ & $\begin{array}{l}3.2477 \\
(1.79) *\end{array}$ & Log(Size) & $\begin{array}{l}0.0376 \\
(3.09)^{* * *}\end{array}$ & $\begin{array}{l}0.0377 \\
(1.63)\end{array}$ \\
\hline Age & $\begin{array}{l}-26.2452 \\
(-2.15)^{* *}\end{array}$ & $\begin{array}{l}-0.3459 \\
(-0.12)\end{array}$ & Log(Age) & $\begin{array}{l}-0.0402 \\
(-1.54)\end{array}$ & $\begin{array}{l}-0.0052 \\
(-0.09)\end{array}$ \\
\hline Part_EPP & $\begin{array}{l}451.906 \\
(2.68)^{* * *}\end{array}$ & $\begin{array}{l}41.0366 \\
(0.79)\end{array}$ & Part_EPP & $\begin{array}{l}0.0338^{* * *} \\
(2.57)\end{array}$ & $\begin{array}{l}0.0072 \\
(0.20)\end{array}$ \\
\hline $\begin{array}{l}\text { Year } \\
\text { Dummy }\end{array}$ & Yes & Yes & $\begin{array}{l}\text { Year } \\
\text { Dummy }\end{array}$ & Yes & Yes \\
\hline Obs & 1303 & 366 & Obs & 1238 & 219 \\
\hline $\mathbf{R}^{2}$ & 0.5577 & 0.0238 & $\mathbf{R}^{2}$ & 0.0516 & 0.0600 \\
\hline Const & $\begin{array}{l}-555.2348 \\
(-1.05)\end{array}$ & $\begin{array}{l}49.6975 \\
(0.56)\end{array}$ & Const & $\begin{array}{l}0.3575 \\
(4.23)^{* * *}\end{array}$ & $\begin{array}{l}0.0489 \\
(0.32)\end{array}$ \\
\hline
\end{tabular}

Note: values enclosed between parentheses are Z statistics; ${ }^{* * *} p<0.01 ;{ }^{* *} p<0.05 ;{ }^{*} p<0.1$.

Overall, results of the robustness checks, reported in Tables 9 and 10, are consistent with those previously presented and discussed, in terms of coefficient signs, magnitude, and statistical significance level.

Results document that EPP is correlated with more exports but only in firms that have had prior export experience. Additionally, single exposure to EPP did not significantly increase exports but multiple exposure did. This suggests that firms need to learn about exports for EPP to be more effective, that EPP helps firms build on experience rather than simply overcoming the barriers, and that EPPs may not have given enough impetus for firms to enter export markets being the positive effect is driven by the firms that are heavy users of EPP.

\section{Conclusions and Limitations}

The global economy, increasingly complex, has increased the importance of the internationalization of businesses, forcing them to increase competitiveness to face unpredictable changes. Thus, understanding the importance of internationalization support mechanisms is essential.

EPPs are intended to improve the businesses export performance, which in turn helps countries to exploit their full export potential. Thus, this paper sought to assess the influence of EPPs on the export performance of Portuguese firms.

In this sense, data were collected on a set of Portuguese firms that participated in at least one of four export promotion programs mediated by a regional development association. The data were collected from two different sources: the regional development association and the SABI database. The regional development association was important to obtain information on the firms that participated in the EPPs, as well as on the characteristics of the EPPs. The SABI database was important to obtain economic information of the firms that participated in the EPPs. Data for the period from 2010 to 2018 were considered and in total data were collected from 198 firms over these years to identify the effect of participation in EPPs on the export performance.

Two models were estimated to strengthen the results obtained. Alternative specifications were used, and in the two models it was found that the variable participation in EPPs has always remained relevant, regardless of the model.

It is possible to conclude that larger firms with more resources influence positively the export performance, whereas age effect on export performance is negative suggesting that the characteristics of older firms-e.g., cultural inertia, lower flexibility, or inability to deploy strategies to cope with new markets-slow their response to changes, namely the 
ones related with EPPs and export performance when compared with younger firms. In addition, it was also concluded that EPPs can be favorable to firms that intend to export or improve their export process and have a positive effect on their export activity, confirming the importance for businesses to participate on these programs. Moreover, this paper consolidates previous experiences of EPPs at national level, as it is expected that local and regional development associations have more proximity to the firms than national entities and could be more influential in involving SMEs in participating in export promotion programs than national entities or bodies that are normally quite distant from the regular SME.

The robustness checks also confirm the importance of the resources and capabilities. It is possible to conclude that the internal resources and capabilities are very important if firms want to properly explore EPPs as only firms with previous export experience seem to have a positive effect on firms' exports. As such, one can claim that to succeed abroad using EPPs, firms need to invest and nurture their internal resources and capabilities. Furthermore, only those firms that participate in several EPPs seem to take full advantage of them. As such, it is possible to conclude that the participation in an EPP just for curiosity does not pay off. Clearly, firms will have to invest in their resources and capabilities and in knowledge gaining strategies-e.g., participating in a EPP, but will have also to internalize the knowledge gained in order to properly explore foreign markets through EPPs.

These results are favorable for business managers and owners who want to start or deepen their export process and need support in their internationalization path. Furthermore, it is important to understand more deeply the behavior of firms in these types of programs, in order to improve the efficiency and effectiveness when participating in EPPs.

In addition, it is advisable that policy-makers need to support and finance the use of these programs through local and regional development agencies and associationsnormally closer to their local/regional associated firms-which not only leads to an improvement in the export performance of firms, but also to an improvement of the country's economic well-being.

Although it was possible to answer the research question, this investigation has some limitations and, as such, its results should be treated with some caution since they cannot be generalized to the entire population. First, the sample is composed of firms that were supported by a regional development entity, which implies some contextual homogeneity. Second, the regional development association, although provided information about the export promotion programs organized, was relatively conservative in releasing information and data for the analysis of the firms. As such, it was only possible to work with the economic data obtained from the SABI database.

Other explanatory variables could have been used, such as resources and capacities related to the businesses export activity, the year the export activity started, the number of countries to which they exported and started to export, among others. It would also be interesting to make a distinction between types of export promotion programs, which would make the study more enriching. Unfortunately, these data have not been released.

A large sample would allow comparisons between the behavior of firms not only by size-small, medium and large- - but also by type of program. Thus, in future research the analysis could be extended to other variables and distinctions and applied to a larger number of firms and with other characteristics. Additionally, it would be interesting to study how export barriers prevent firms from exporting, to facilitate their mitigation.

Author Contributions: All authors contributed equally. All authors have read and agreed to the published version of the manuscript.

Funding: This work was financially supported by the research unit on Governance, Competitiveness and Public Policy (UIDB/04058/2020), funded by national funds through FCT—Fundação para a Ciência e a Tecnologia. 
Data Availability Statement: The data are not publicly available. Some data was obtained from a Portuguese Regional Development Association, which is not publicly available. Some data was obtained from the SABI database.

Acknowledgments: We would like to thank the anonymous referees for their useful comments and constructive suggestions.

Conflicts of Interest: The authors declare no conflict of interest.

\section{References}

Alvarez, Roberto. 2004. Sources of Export Success in Small- and Medium-sized Enterprises: The Impact of Public Programmes. International Business Review 13: 383-400. [CrossRef]

Ayob, Abu, and Joan Freixanet. 2014. Insights into Public Export Promotion Programmes in an Emerging Economy: The Case of Malaysian SMEs. Evaluation and Programme Planning 46: 38-46. [CrossRef]

Barney, Jay. 1991. Firm Resources and Sustained Competitive Advantage. Journal of Management 17: 99-120. [CrossRef]

Cansino, José, Jaime Lopez-Melendo, Maria Pablo-Romero, and Antonio Sánchez-Braza. 2013. An economic evaluation of public programmes for internationalization: The case of the Diagnostic programme in Spain. Evaluation and Programme Planning 41: 38-46. [CrossRef] [PubMed]

Comi, Simona, and Laura Resmini. 2020. Are export promotion programmes effective in promoting the internalization of SMEs? Economia Politica 37: 547-81. [CrossRef]

Coudounaris, Dafnis. 2012. Effective Targeting of National Export Promotion Programmes for SMEs. International Journal of Globalisation and Small Business 4: 242-83. [CrossRef]

Coudounaris, Dafnis. 2018. Export Promotion Programmes for Assisting SMEs. Review of International Business and Strategy $28:$ 77-110. [CrossRef]

Crick, Dave. 1992. UK Export Assistance: Are we Supporting the Best Programmes? Journal of Marketing Management 8: 81-92. [CrossRef]

Dominguez, Noémi. 2018. Promotion Agencies and SMEs' Internationalization Process: A Blessing or a Curse? Journal of International Entrepreneurship 16: 58-81. [CrossRef]

Duygulu, Ethem, Emir Ozeren, Pınar Işıldar, and Andrea Appolloni. 2016. The Link Between Mission Statements and Performance: Formulating The Right Strategy for Small and Medium Sized Enterprises (SMEs). Sustainability 8: 698. [CrossRef]

Fernández, Zulima, and Maria José Nieto. 2005. Internationalization Strategy of Small and Medium-sized Family Businesses: Some Influential Factors. Family Business Review 18: 77-89. [CrossRef]

Francis, June, and Colleen Collins-Dodd. 2004. Impact of Export Promotion Programmes on Firm Competencies, Strategies and Performance: The Case of Canadian High-technology SMEs. International Marketing Review 21: 474-95. [CrossRef]

Freixanet, Joan. 2012. Export Promotion Programmes: Their Impact on Companies' Internationalization Performance and Competitiveness. International Business Review 21: 1065-86. [CrossRef]

Furtado, Julia, Ana Pereira, Inês Pereira, and António C. Moreira. 2019. Does Theory Really Fit Real Life Situations?: A Case Study on the Internationalization Process of a Technological Service-based Firm. In Handbook of Research on Entrepreneurship, Innovation, and Internationalization. Edited by Nuno Teixeira, Teresa da Costa and Inês Lisboa. Hershey: IGI Global, pp. 419-38. [CrossRef]

Geldres-Weiss, Valeska, and Joaquín Monreal-Pérez. 2018. The Effect of Export Promotion Programmes on Chilean Firms' Export Activity: A Longitudinal Study on Trade Shows and Trade Missions. Journal of Promotion Management 24: 660-74. [CrossRef]

Geldres-Weiss, Valeska, Claudine Uribe-Bórquez, Dafne Coudounaris, and Joaquín Monreal-Pérez. 2016. Innovation and experiential knowledge in firm exports: Applying the initial U-model. Journal of Business Research 69: 5076-81. [CrossRef]

Gençtürk, Esra, and Masaaki Kotabe. 2001. The Effect of Export Assistance Programme usage on Export Performance: A Contingency Explanation. Journal of International Marketing 9: 51-72. [CrossRef]

Grant, Robert. 1991. The Resource-based Theory of Competitive Advantage: Implication for Strategy Formulation. California Management Review 33: 114-35. [CrossRef]

Haddoud, Mohamed, Adah-Kole Onjewu, Paul Jones, and Robert Newbery. 2018. Investigating the Moderating role of Export Promotion Programmes using Evidence from North-Africa. Critical Perspectives on International Business 14: 282-308. [CrossRef]

Hausman, Jerry. 1978. Specification Tests in Econometrics. Econometrica 46: 1251-71. [CrossRef]

Jalali, Seyed. 2012. The Effect of Export Promotion Programmes on Export Performance: Evidence from Iranian Food Manufacturers. International Journal of Business and Globalisation 9: 122-33. [CrossRef]

Johanson, Jan, and Jan-Erik Vahlne. 2009. The Uppsala Internationalization Process Model Revisited: From Liability of Foreignness to Liability of Outsidership. Journal of International Business Studies 40: 1411-31. [CrossRef]

Kang, Kichun. 2011. Overseas Network of Export Promotion Agency and Export Performance: The Korean Case. Contemporary Economic Policy 29: 274-83. [CrossRef]

Katsikeas, Constantine, Leonidas Leonidou, and Niel Morgan. 2000. Firm-level Export Performance Assessment: Review, Evaluation, and Development. Journal of the Academy of Marketing Science 28: 493-511. [CrossRef]

Kirpalani, Vishnu H., and Norman B. Macintosh. 1980. International Marketing Effectiveness of Technology-oriented Small Firms. Journal of International Business Studies 11: 81-90. [CrossRef] 
Leonidou, Leonidas, Constantine Katsikeas, Dayananda Palihawadana, and Stavroula Spyropoulou. 2007. An Analytical Review of the Factors Stimulating Smaller Firms to Export: Implications for Policy-makers. International Marketing Review 24: 735-70. [CrossRef]

Leonidou, Leonidas, Dayananda Palihawadana, and Marios Theodosiou. 2011. National Export-promotion Programmes as Drivers of Organizational Resources and Capabilities: Effects on Strategy, Competitive Advantage, and Performance. Journal of International Marketing 19: 1-29. [CrossRef]

Li, Kai, and Nagpurnanand Prabhala. 2007. Self-Selection Models in Corporate Finance. In Handbook of Empirical Corporate Finance. Edited by B. Espen Eckbo. San Diego: Elsevier, pp. 37-86.

Love, James, Stephen Roper, and Ying Zhou. 2016. Experience, Age and Exporting Performance in UK SMEs. International Business Review 25: 806-19. [CrossRef]

Lu, Jane, and Paul Beamish. 2001. The Internationalization and Performance of SMEs. Strategic Management Journal 22: 565-86. [CrossRef]

Malca, Oscar, Jesús Peña-Vinces, and Francisco Acedo. 2020. Export Promotion Programmes as Export Performance Catalysts for SMEs: Insights from an Emerging Economy. Small Business Economics 55: 831-51. [CrossRef]

Mata, Mario, Muhammand Falahat, Anabela Correia, and João Rita. 2021. Impact of Institutional Support on Export Performance. Economies 9: 101. [CrossRef]

Melitz, Marc. 2003. The Impact of Trade on Intra-industry Reallocations and Aggregate Industry Productivity. Econometrica 71: 1695-725. [CrossRef]

Monreal-Pérez, Joaquín, Antonio Aragón-Sánchez, and Gregorio Sánchez-Marín. 2012. A Longitudinal Study of the Relationship between Export Activity and Innovation in the Spanish Firm: The Moderating role of Productivity. International Business Review 21: 862-77. [CrossRef]

Morgan, Robert. 1997. Export Stimuli and Export Barriers: Evidence from Empirical Research Studies. European Business Review 97: 68-79. [CrossRef]

Mota, Jorge, and António C. Moreira. 2017. Determinants of the Capital Structure of Portuguese Firms with Investments in Angola. South African Journal of Economic and Management Sciences 20: a885. [CrossRef]

Neuman, William. 2012. Social Research Methods: Qualitative and Quantitative Approaches. New York: Pearson.

Osland, Gregory, Charles Taylor, and Shaoming Zou. 2001. Selecting International Modes of Entry and Expansion. Marketing Intelligence $\mathcal{E}$ Planning 19: 153-61. [CrossRef]

Oviatt, Benjamim, and Patricia McDougall. 1997. Challenges for Internationalization Process Theory: The Case of International New Ventures. Management International Review 37: 85-99.

Paul, Justin, and Parul Gupta. 2014. Process and Intensity of Internationalization of IT Firms: Evidence from India. International Business Review 23: 594-603. [CrossRef]

Paul, Justin, and Rosário Sánchez-Morcilio. 2019. Toward a new model for firm internationalization: Conservative, predictable, and pacemaker companies and markets. Canadian Journal of Administrative Sciences 36: 336-49. [CrossRef]

Peteraf, Margaret, and Jay Barney. 2003. Unraveling the Resource-Based Tangle. Managerial and Decision Economics 24: 309-23. [CrossRef]

Quaye, Daniel, Kwame Sekyere, and George Acheampong. 2017. Export Promotion Programmes and Export Performance: A Study of Selected SMEs in the Manufacturing Sector of Ghana. Review of International Business and Strategy 27: 466-83. [CrossRef]

Ribau, Cláudia, António C. Moreira, and Mário Raposo. 2015. Internationalisation of the Firm Theories: A Schematic Synthesis. International Journal of Business and Globalisation 15: 528-54. [CrossRef]

Ribau, Cláudia, António C. Moreira, and Mário Raposo. 2018a. SME Internationalization Research: Mapping the State of the Art. Canadian Journal of Administrative Sciences 35: 280-303. [CrossRef]

Ribau, Cláudia, António C. Moreira, and Mário Raposo. 2018b. SMEs Innovation Capabilities and Export Performance: An Entrepreneurial Orientation View. Journal of Business Economics and Management 18: 920-34. [CrossRef]

Sharma, Revti, Gloria Sraha, and Dave Crick. 2018. Export promotion programmes and the export performance of Ghanaian firms: The mediating role of foreign market attractiveness. International Marketing Review 35: 661-82. [CrossRef]

Sobh, Rana, and Chad Perry. 2006. Research Design and Data Analysis in Realism Research. European Journal of Marketing 40: 1194-209. [CrossRef]

Tiago, Maria, João Couto, José Vieira, and Francisco Silva. 2008. The Propensity And Intensity of Export Activities of Companies Operating in Europe. The Journal of Applied Business Research 24: 83-96. [CrossRef]

Westhead, Paul, Deniz Ucbasaran, and Martin Binks. 2004. Internationalisation Strategies Selected by Established Rural and Urban SMEs. Journal of Small Business and Enterprise Development 11: 8-22. [CrossRef]

Wilkinson, Timothy, and Lance Brouthers. 2006. Trade Promotion and SME Export Performance. International Business Review 15: 233-52. [CrossRef]

Wilkinson, Timothy, Lance Brouthers, Dalina Salazar, and Mary McNally. 2009. The Strategic Impact of International Trade Shows and Trade Missions for Entrepreneurial Firms. Journal for Global Business Advancement 2: 207-20. [CrossRef] 